Article

\title{
Flooding Urban Landscapes: Analysis Using Combined Hydrodynamic and Hydrologic Modeling Approaches
}

\author{
Manoj K. Jha *(D) and Sayma Afreen \\ Civil, Architectural, and Environmental Engineering, North Carolina A\&T State University, Greensboro, \\ NC 27411, USA; safreen@aggies.ncat.edu \\ * Correspondence: mkjha@ncat.edu
}

Received: 26 May 2020; Accepted: 11 July 2020; Published: 14 July 2020

check for updates

\begin{abstract}
The frequency and severity of floods have been found to increase in recent decades, which have adverse effects on the environment, economics, and human lives. The catastrophe of such floods can be confronted with the advance prediction of floods and reliable analyses methods. This study developed a combined flood modeling system for the prediction of floods, and analysis of associated vulnerabilities on urban infrastructures. The application of the method was tested on the Blue River urban watershed in Missouri, USA, a watershed of historical significance for flood impacts and abundance of data availability for such analyses. The combined modeling system included two models: hydrodynamic model HEC-RAS (Hydrologic Engineering Center-River Analysis System) and hydrologic model SWAT (Soil and Water Assessment Tool). The SWAT model was developed for the watershed to predict time-series hydrograph data at desired locations, followed by the setup of HEC-RAS model for the analysis and prediction of flood extent. Both models were calibrated and validated independently using the observed data. The well-calibrated modeling setup was used to assess the extent of impacts of the hazard by identifying the flood risk zones and threatened critical infrastructures in flood zones through inundation mapping. Results demonstrate the usefulness of such combined modeling systems to predict the extent of flood inundation and thus support analyses of management strategies to deal with the risks associated with critical infrastructures in an urban setting. This approach will ultimately help with the integration of flood risk assessment information in the urban planning process.
\end{abstract}

Keywords: flood analysis; hydrologic modeling; hydrodynamic modeling; SWAT; HEC-RAS; flood zone delineation

\section{Introduction}

Over the years, the adverse effects of flooding have increased due to changing climate conditions and human interventions [1]. The major factors which lead communities to increased exposure of such flooding risks include urban expansion, changing demographic features within floodplains, changes in flood regime, and human intervention (social and economic developments) in the ecological system [2]. The hydro-meteorological catastrophes of such floods cannot be totally avoided, but the impacts and after-effects can be managed by developing the effective risk reduction and prevention strategies through applications of advanced geospatial tools and decision support systems [3]. Among the most effective ways of assessing the flood risk to people and infrastructures, one approach is the development and application of flood models which identify areas prone to flooding events and support risk analysis and mitigation processes [4]. Flood modeling has provided an indispensable tool to inform the development of the robust flood risk management strategies to avoid or mitigate the adverse impacts of 
floods on individuals, communities, and critical infrastructures such as transportation routes, hospitals, and others. A reliable flood model could alert the flood risk areas and warn the vulnerable population to relocate before the hazards take place. This will potentially alleviate the extent of devastation due to flooding and nullify causalities.

Flood modeling alludes to the process of transformation of rainfall into flood hydrographs which are then hydraulically translated into the depths of water at a spatial scale throughout the watershed [5]. Hydraulic models play an important role in determining flood inundation areas using sets of hydrodynamic equations. One of the major input data is the information on flood hydrographs at multiple locations as upstream and/or lateral boundary conditions. While these data can be obtained from observation data at gaging stations, these are often very limited or not available. Hydrologic rainfall-runoff models are thus frequently used, which when calibrated and validated to a reasonable accuracy, provide hydrograph information at desired locations. There are numerous studies that have independently evaluated the performance of hydrologic models [6-10] and hydrodynamic models [11-14] for their ability to perform the tasks they are developed for. New and improved algorithms have been continuously improving and evolving while capturing more robust simulation approaches and improved capabilities. Over the years, research efforts have been made to improve the numerical accuracy and computational efficiency of hydrodynamic flood models. However, the existing models are still computationally prohibitive for large-scale applications, especially in urban environments where high-resolution representation of complicated topographic features is necessary [14,15]. Similarly, hydrologic models can be computationally efficient in simulating hydrological processes but at the price of representing less detailed physical processes.

There have been several attempts combining hydrodynamic model with hydrological model which may compliment and overcome the shortcomings of either type of modeling approach. The integration of these models can be done various ways. External coupling uses the pre-acquired hydrographs from hydrological models as the upstream and/or lateral boundary conditions for the hydrodynamic models in flood routing analysis through complicated river network systems [16-18]. In the internal coupling method, governing equations of the hydraulic models and hydrological models are solved separately, with information at the shared boundaries updated and exchanged at each or several computational time steps [19]. Fully coupling of these models are not very well understood due to the complexities of reformulating and simultaneously solving governing equations in a single code base [14]. Other approaches include a hybrid method where a 2-D hydrodynamic model is combined with simplified unit hydrographs derived using variations of shallow-water equations [20-24] and integrated catchment models, suitable for flash flood modeling that simulate the complete hydrology and flow, generating runoff, leading to discharge, and then to flooding [25].

Combining hydrodynamic and hydrologic models for flood prediction and analysis is not new. However, the continuous modeling advances and the increase in computational resources over the years make it feasible to conduct flood simulations in high spatial resolution for flood risk assessment. In addition, scientific literature in combining of these two modeling approaches for urban flood simulation is limited [14], and thus underscores the need to continuously develop and apply robust models of improved capabilities for more efficient and accurate analysis. This study demonstrates the flood modeling and analysis method using advanced modeling tools of the present time via the combined or external coupling of hydrodynamic and hydrologic models. The hydrologic model, namely the Soil and Water Assessment Tool (SWAT) [26], was used to derive flow hydrographs at designated locations, which then fed into the hydrodynamic model, namely the Hydrologic Engineering Center's River Analysis System (HEC-RAS) [27] for flood prediction. Both models were independently calibrated and validated using sets of input databases, calibration techniques, observation data, and statistical performance evaluation methods. The combined application was used for flood simulations and the identification of the extent of inundation. The analysis provided the assessment of the impact of flood hazards by the identification of flood risk zones and the threatened infrastructures. The approach was applied in the Blue River Watershed in Missouri, USA, which has historic significance 
with respect to frequent severe floods. The watershed provides a rich database of observation data developed over the years. The combined modeling system provides crucial flood risk information necessary for the development of an accurate and reliable forecasting system for assist in evacuation, relief operation route, cost estimation of the damaged properties, and other pertinent information.

\section{Materials and Methods}

The method included development of two mathematical models: SWAT and HEC-RAS. The SWAT model was developed via Geographic Information System (ArcGIS) interface of the model, called ArcSWAT, using a set of spatial datasets including topography data (digital elevation model), land use data (National Land Cover Database), and soil types and soil characteristics data (State Soil Geography Database), as well as time-series daily dataset on meteorological parameters, including precipitation, maximum and minimum temperature, wind speed, solar radiation, and relative humidity. The model was calibrated for the overall watershed hydrological water balance followed by monthly streamflow at a gaging location at the watershed outlet by comparing model simulated values with the observation data collected at the gaging site. Once the model is calibrated and validated with satisfactory statistical performance measures, it was then used to develop a series of simulated streamflow hydrographs to be used as an input to the HEC-RAS model.

The HEC-RAS model was developed for river segments within the watershed. The geometric data and the Manning's roughness coefficient values (n) were established for the modeling setup using ArcGIS interface of the model, called HEC_geoRAS. It was then calibrated and validated using the past flood data collected from the USGS gaging stations within the study area.

The flow chart in the Figure 1 portrays different step of the processes performed in this study. Based on the streamflow input from calibrated SWAT model, the calibrated HEC-RAS model predicts flood levels and the extent of the flood in the surrounding landscapes. Further analysis was conducted to identify vulnerabilities of critical infrastructures including hospitals, railroads, airports, and transportation routes by examining the proximities of these infrastructures from the flood zones.

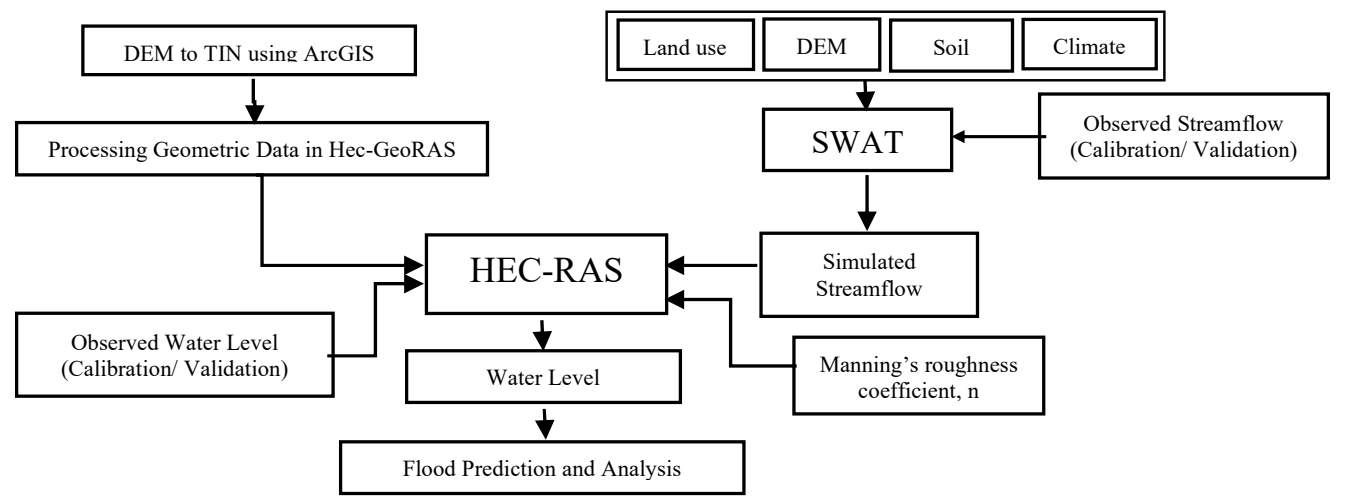

Figure 1. Schematic of data and models for flood prediction and analysis.

\subsection{Study Area}

The Blue River also known as Big Blue River is a part of tributaries of Missouri River located in Kansas City, Missouri (Figure 2). The Blue River watershed extends from the south of Johnson County in Kansas State into the State of Missouri and drains an area of $658.9 \mathrm{~km}^{2}$ into the Missouri River in Kansas City, Jackson County, Missouri. The Blue River Watershed spreads over roughly one-half of the Kansas City metropolitan area south of the Missouri River. The watershed course through two states (Missouri and Kansas), four counties (Johnson and Wyandotte in Kansas; Jackson and Cass in Missouri), and 11 municipalities [28]. The Blue River is 39.8 mile $(64.1 \mathrm{~km})$ long stream, and the mouth of the river is at 221 feet elevation in the east of Johnson County near the borders of the states of Kansas and Missouri. The percentage of Blue river watershed within the state of Missouri is about 
$46 \%$, which is within the Kansas City metropolitan area. The area is moderately to highly developed and contain a mix of residential and commercial structures and is subjected to flooding every year due to urban development, dense soils, and the configuration of the Blue River basin [29]. The lower part of the watershed is primarily industrial, whereas the middle and upper part are rapidly being converted to residential areas [30]. Due to the flood sensitive nature of this river zone, U.S. Geological Survey (USGS) has been studying this area closely and acquired an extensive dataset over the time. The abundance of data in this location was very helpful in accurately calibrating the mathematical models for flood prediction and the analysis objective of this study.

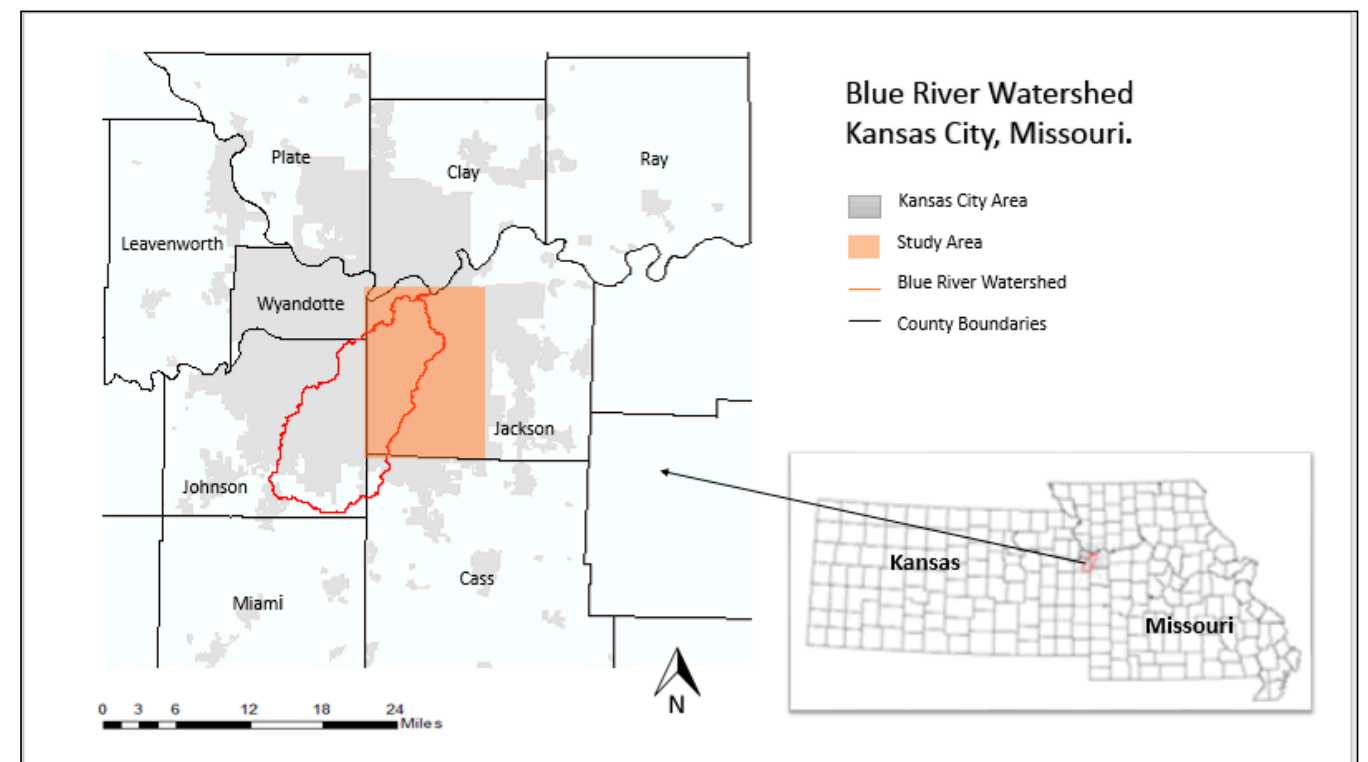

Figure 2. Blue River Watershed in Kansas City, Missouri, USA.

\subsection{Data Collection}

The development of the combined modeling system required extensive data collection from various sources. Table 1 lists some of the major data types and their sources. Subsections below provided more specific information on data collection efforts.

Table 1. Datasets and their sources used for creating the combined modeling system.

\begin{tabular}{cc}
\hline Dataset & Source \\
\hline Digital Elevation Model (DEM) & United States Geological Survey (USGS)-The National Map \\
Streamflow & United States Geological Survey (USGS) \\
Gage Height & United States Geological Survey (USGS) \\
Land Use & National Land Cover Database (NLCD) \\
Climate Data & National Oceanic \& Atmospheric Administration (NOAA) \\
Soil Classification & State Soil Geography Database (STATGO) \\
\hline
\end{tabular}

\subsection{Hydrologic Model Overview-SWAT}

SWAT is a river basin scale model developed to predict the impact of land management practices on water, sediment and agricultural chemical yields in large complex watershed with varying soils, land use and management conditions over extended periods of time [6,20]. SWAT is a long-term yield model extensively used to simulate watersheds on multiple spatial-temporal scales including hydrological processes [7,9,31,32], fate and transport of sediment and nutrients [33-35], land use change [36], climate change [37-43], and others.

The major inputs required to develop a SWAT model are topographical data which are used to define stream network and delineate a number of subwatersheds; land use data, soil data, and slope information to delineate each subwatershed into hydrologic response units (HRUs) which 
represents unique combination of land use, soil types, and slope; (3) the daily time-series information on meteorological parameters, and (4) the model's inbuilt databases and initialization assumptions. The outputs include spatiotemporal time-series data on water balance components, streamflow, sediment and nutrient loadings, and others.

\subsubsection{Modeling Setup and Watershed Delineation}

The Blue River Watershed was delineated using stream generation functionality in ArcGIS based on the supplied $10 \mathrm{~m}$ resolution DEM projected in Northern America Datum NAD_1983 UTM zone 15N. The delineated subwatersheds (Figure 3) were further subdivided into multiple lumped units within each subwatershed. These lumped units are called HRUs, a unique combination of land use, slope, and soil types. An HRU represents a percentage of a sub-watershed area and not spatially identified within a subwatershed. All water balance calculations and modeling simulations are conducted at the HRU level. Outputs from each HRU within a subwatershed are aggregated at the subwatershed level which are then routed through the streams leading to the next downstream subwatershed. Outputs from each subwatershed are subsequently routed all the way to the watershed outlet on a daily basis. Muskinghum method was used in the hydrologic routing process. Other methods include Curve-Number approach for flow generation, and Penman-Moneith method for the estimation of evapotranpiration.

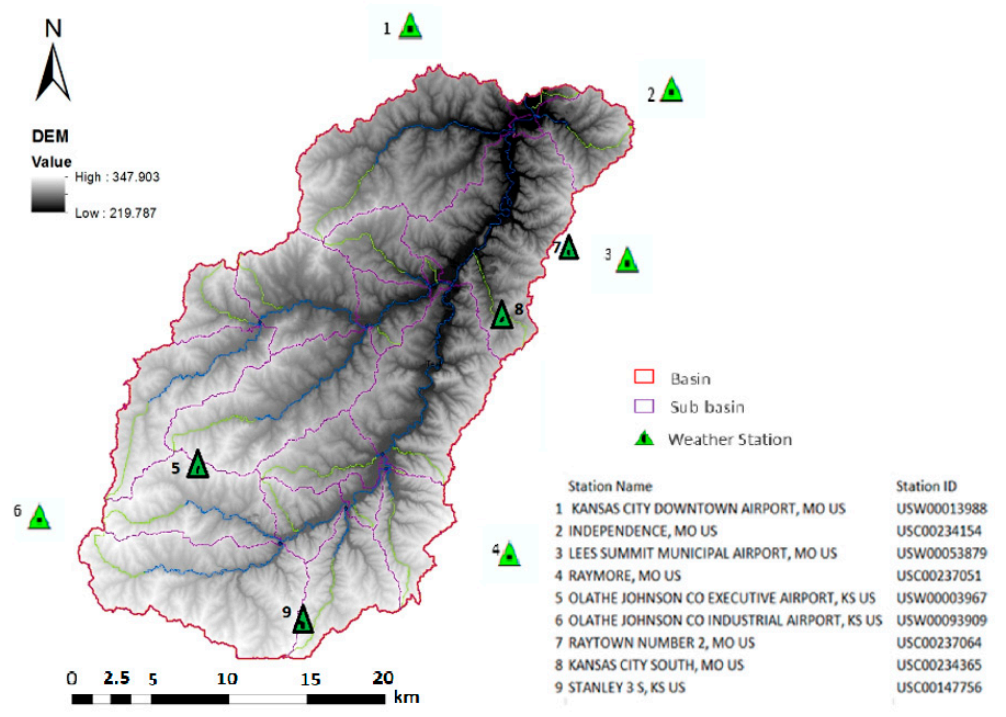

Figure 3. Delineation of Blue River Watershed and location of NOAA weather stations.

The land use data was obtained from National Land Cover Dataset (NLCD) from 2011 (https: //www.mrlc.gov/nlcd11_data.php). Classification of the land use data was found to cover dense urban areas (48\%), developed open area $(20 \%)$, pasture/hay $(13.5 \%)$, forest $(9 \%)$, cultivated crops $(7 \%)$, grassland $(1 \%)$, open water $(0.6 \%)$, wetland $(0.5 \%)$, shrub $(0.2 \%)$, and barren land $(0.2 \%)$. The soil data source was State Soil Geographic (STATSGO) database (https://catalog.data.gov/dataset/statsgo) which was already included in the ArcSWAT inbuilt datasets. Figure 4 presents reclassified land use, soil types and slope categories used in HRU delineation. The time-series meteorological information was obtained for 9 weather stations located in and around the watershed (Figure 3) using data download function at the NOAA-NCDC website (https://www.ncdc.noaa.gov/cdo-web/datatools/findstation). 

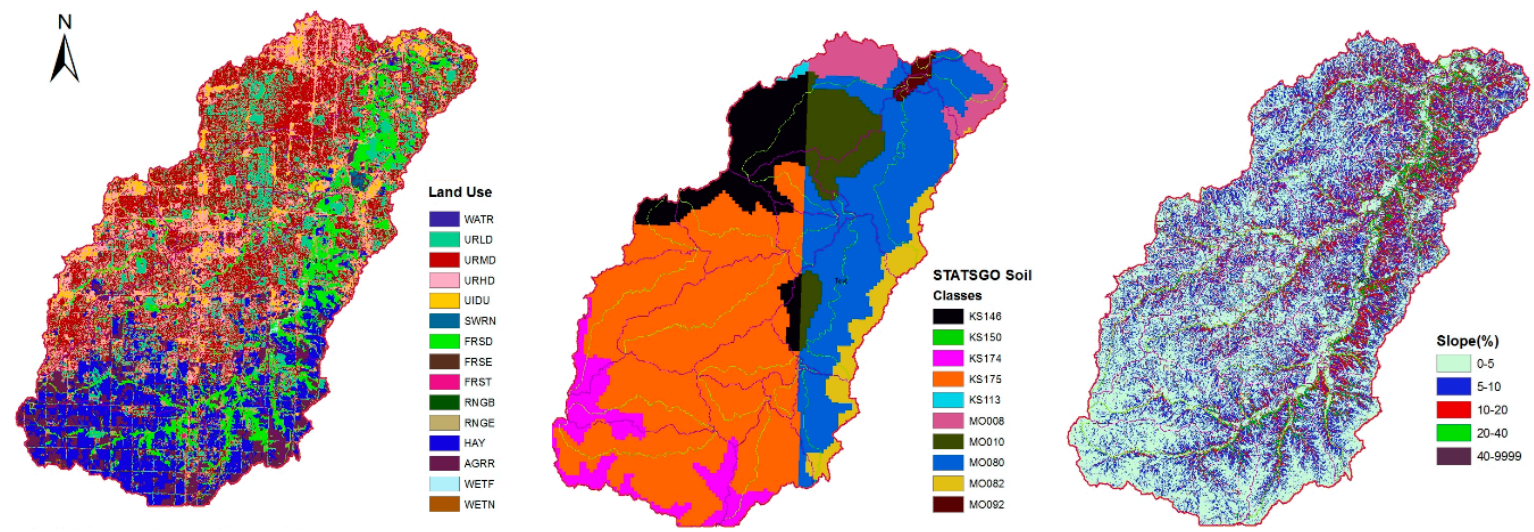

Figure 4. Reclassified land use, soil and slop data used in the HRU delineation.

\subsubsection{SWAT Simulation and Calibration/Validation Approach}

The SWAT modeling setup was executed on a daily time step for 8 years of simulation from 2010-2017 (2-year warm-up, 4-year calibration, and 2-year validation period). Calibration and validation of the SWAT model was performed using SWAT's Calibration and Uncertainty Program, SWAT-CUP [44]. This autocalibration tool can perform sensitivity analysis, calibration, validation, and uncertainty analysis. Sensitivity analysis of the model's hydrologic parameters were conducted and ten parameters were identified as the most sensitive. There are runoff curve number (CN2), soil evaporation compensation factor (ESCO), water holding capacity of the soil (SOL_AWC), plant uptake compensation factor (EPCO), groundwater revap coefficient (GW_REVAP), base flow alpha factor (ALPHA_BF), threshold depth of water in the shallow aquifer required for return flow (REVAPMN), groundwater delay (GW_DELAY), surface runoff lag coefficient (SURLAG), and threshold depth of water in the shallow aquifer required for return flow to occur (GWQMN). The details of these model parameters can be found in the User's Manual. In the calibration process, defaulted values of these parameters were adjusted within their permissible ranges to a final calibrated value after comparing simulated results with the observations with acceptable performance measures tested through statistical procedures [39]. The autocalibration tool identified the best fitted values of all ten parameters while fitting the monthly comparison of simulated flow values with the observations from gaging stations at the watershed outlet. Statistical evaluation was conducted using four indicators: coefficient of determination $\left(\mathrm{R}^{2}\right)$, Nash-Sutcliff's efficiency (NSE), percentage bias (PBIAS), and RMSE standard deviation ratio (RSR). Calibration process concluded with satisfactory performance in visual comparison and acceptable statistical comparisons. During the validation process, the model was executed with already defined value of calibration parameters (no further), followed by the same statistical evaluation as that of the calibration duration.

\subsection{Hydrodynamic Model Overview-HEC-RAS}

HEC-RAS [21] can perform one and two-dimensional hydrodynamic calculations for a full network of natural and constructed channels. The major capabilities of HEC-RAS are user interface, hydraulic analysis components, data storage and management, graphics and reporting, and RAS Mapper. The HEC-RAS system accommodates several river analysis components for steady and unsteady flow water surface profile computations, movable boundary sediment transport computations and water quality analysis. Hydrodynamic equations calculate water surface elevations at all locations of interest for a given peak flood. The major data inputs are river geometric cross-section data, river floodplain data (length, elevation), the distance between successive river cross-sections, manning roughness coefficient values (n) for the land use type covering the river and the floodplain area, and boundary conditions (flow hydrograph and normal depth). Under steady flow, the boundary conditions are a discharge 
upstream and a stage downstream. The model proceeds to calculate stages throughout the interior points, keeping the discharge constant in space. Under unsteady flow, a discharge hydrograph is the upstream boundary and a discharge-stage rating at the downstream boundary. The model calculates discharges and stages throughout the interior points. Unsteady flow simulation uses the Saint-Venant equations or the diffusion wave equations using an implicit finite volume algorithm. The outputs from the HEC-RAS model include water surface elevations, rating curves, hydraulic properties (energy grade line slope, elevation, flow area, velocity), and visualization of the extent of flooding.

The steady flow simulation based on a peak flow discharge throughout the river line represents the water flow without any change over time. It consists of flow regime, discharge information and boundary condition. Multiple profiles can be created with different discharge values. The unsteady flow simulation is developed with a series of discharge data with respect to the time of occurrence. The data required for the unsteady flow simulations include boundary conditions (external and internal) and initial conditions.

The calibration of the model was initiated by calibrating for the steady flow simulation followed by the calibration of the unsteady flow simulations. The model was calibrated for a peak flow event at five USGS gaging stations (Figure 5) with adjustments in the parameters such as Manning's n value and required boundary conditions [21]. The upstream boundary condition was a flow hydrograph and the downstream boundary condition was normal depth for steady state simulation. The HEC-RAS was executed to develop water level data which were compared with observed water elevations. After the calibration, the model was validated for two other flood events at all five stations based on the calibrated parameters.

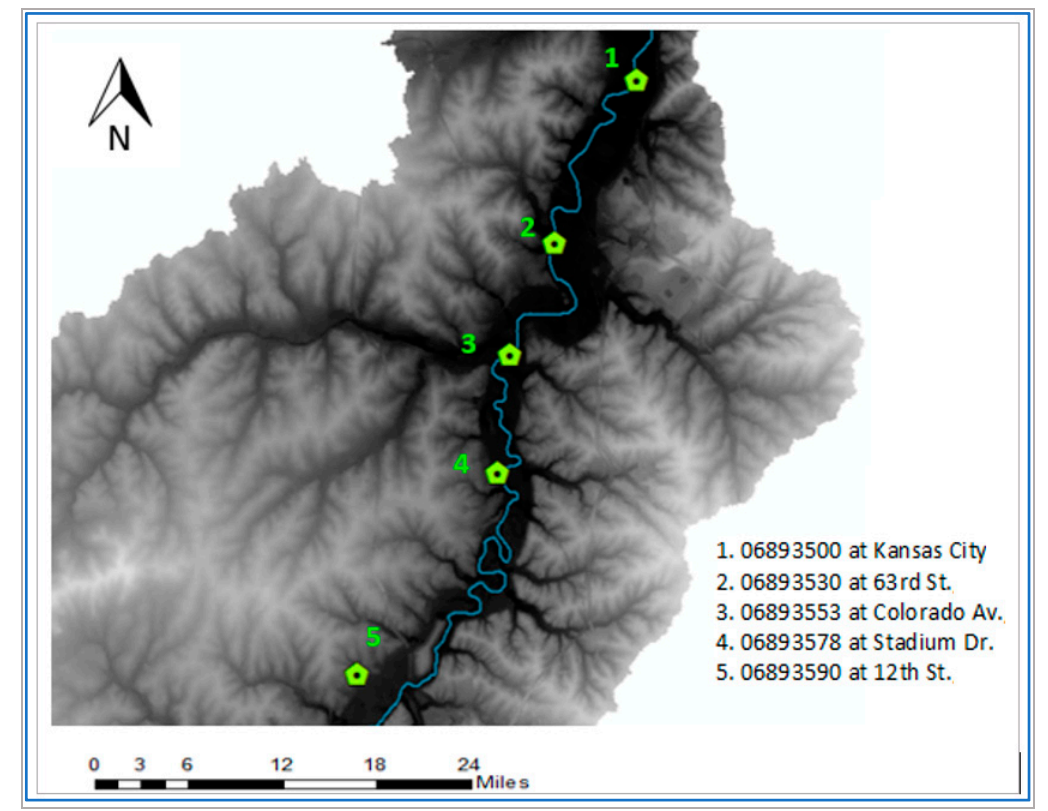

Figure 5. Location of USGS Gaging Stations used in the calibration.

\section{Results and Discussion}

\subsection{Clibration and Validation of the Hydrolgic Model}

The SWAT model developed for the Blue River Watershed was calibrated using the automated calibration technique (SUFI-2) for flow by comparing simulated values with the observations at the watershed outlet (USGS 06893500, Blue river at Kansas City, MO, USA). Table 2 lists all parameters used in the calibration process with their permissible ranges and the final fitted values after the calibration. 
Table 2. List of parameters used for calibration with their ranges and the fitted value.

\begin{tabular}{cccc}
\hline Parameter & Description & Range & Fitted Value \\
\hline CN2 & Curve Number & $-15 \%-15 \%$ & $-5.34 \%$ \\
EPCO & Plant Uptake Compensation Factor & $0.01-1$ & 0.73 \\
SOL_AWC & Water Holding Capacity of Soil & $-0.04-0.04$ & -0.025 \\
GW_REVAP & Groundwater Revap Coefficient & $0.02-0.2$ & 0.05 \\
ALPHA_BF & Base Flow Alpha Factor & $0.05-0.8$ & 0.1 \\
REVAPMN & Threshold Depth, Percolation to deep aq. & $0-500$ & 455 \\
ESCO & Soil Evaporation Compensation Factor & $0.75-0.95$ & 0.81 \\
GW_DELAY & Groundwater Delay & $0-500$ & 476 \\
GWQMN & Threshold Depth, Return flow to occur & $0-1000$ & 868 \\
SURLAG & Surface Runoff Lag Coefficient & 6.7 \\
\hline
\end{tabular}

Figure 6 shows the comparison of simulated versus observed streamflow at the watershed outlet using monthly data. The comparison seems to match well except for slight underprediction of peaks. The hydrograph seems to follow very close for its recession, baseflow and other patterns. Table 3 provides values of statistical measures for both calibration and validation periods. Overall, these values show a strong correlation of the simulated streamflow with the observation. Thus, it can be concluded that the SWAT model was well-calibrated to simulate streamflow with reliable performance in the Blue River Watershed. The calibrated model output was used to generate discharge (streamflow) data at several locations within the watershed to be used as input for the HEC-RAS model.

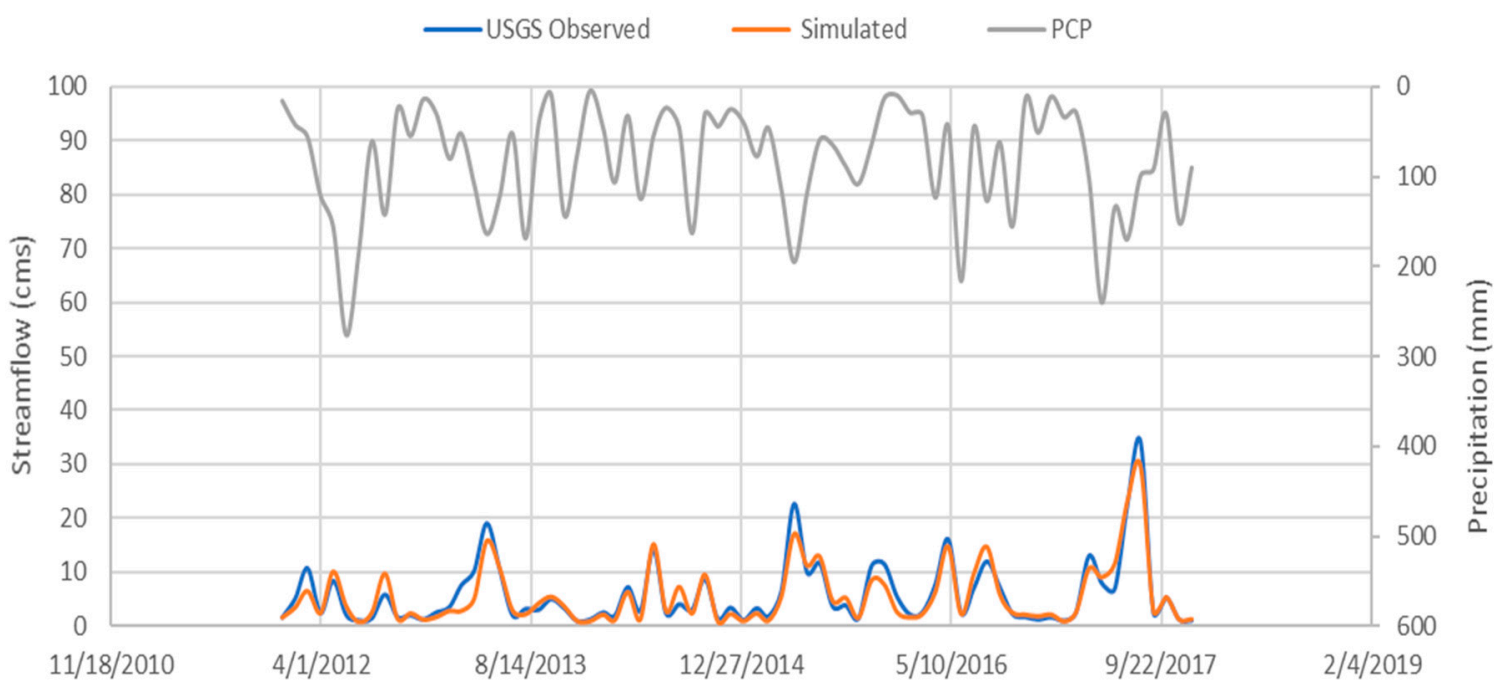

Figure 6. Monthly comparison of simulated and observed streamflow data for the calibration (2012-2015) and validation (2016-2017) periods along with precipitation data for the entire range $\left(\mathrm{cms}^{3} \mathrm{~m}^{3} / \mathrm{s}\right)$.

Table 3. Statistical Evaluation of the calibration \& validation of the Blue River Watershed.

\begin{tabular}{cccc}
\hline Statistical Test & $\begin{array}{c}\text { Calibration Period } \\
\text { 2012-2015 }\end{array}$ & $\begin{array}{c}\text { Validation Period } \\
\text { 2016-2017 }\end{array}$ & $\begin{array}{c}\text { Acceptable Range } \\
\text { [45] }\end{array}$ \\
\hline NSE & 0.83 & 0.92 & NSE $>0.50$ \\
PBIAS (\%) & 9.40 & 3.00 & PBIAS $< \pm 25 \%$ \\
RSR & 0.41 & 0.28 & RSR $<0.70$ \\
R $^{2}$ & 0.84 & 0.93 & R2 $>0.5$ \\
\hline
\end{tabular}

\subsection{Clibration and Validation of the Hydrodynamic Model}

The hydrodynamic model developed for the Blue River by HEC-RAS was calibrated and validated at the five USGS gaging stations located on the River (Figure 5). Model simulated water surface elevations were compared with the observed water surface elevations at the USGS gages. The Manning's roughness coefficient (n) values were adjusted until the simulated values match closely with the values 
at USGS gages. The calibration was performed for the flood event of 17 May 2015 and the results are presented in Table 4 . The results show that the difference between the observed and simulated values were very minimal and thus justify the model's ability to simulate water surface levels. The statistical evaluation using two performance measures NSE and $\mathrm{R}^{2}$ yielded a strong correlation with value of 0.989 and 0.98 respectively. The validation process was conducted for two peak events: the floods on 27 April 2016 and 22 September 2017. The difference in observed and simulated water surface elevations were small and therefore the results are considered satisfactory which is portrayed in Table 5 . It can be concluded that the HEC-RAS model developed for the Blue River performed very well to simulate water surface elevations.

Table 4. HEC-RAS Model Calibration for the flood event of 17 May 2015.

\begin{tabular}{ccccc}
\hline USGS Station & $\begin{array}{c}\text { Flow } \\
\left(\mathbf{m}^{\mathbf{3}} \mathbf{s}\right)\end{array}$ & $\begin{array}{c}\text { Simulated Stage } \\
(\mathbf{m})\end{array}$ & $\begin{array}{c}\text { Observed Stage } \\
(\mathbf{m})\end{array}$ & $\begin{array}{c}\text { Difference } \\
(\mathbf{m})\end{array}$ \\
\hline 06893500 & 298 & 7.8 & 7.7 & -0.06 \\
06893530 & 268 & 7.0 & 7.0 & 0.05 \\
06893553 & 251 & 6.2 & 6.2 & -0.01 \\
06893578 & 229 & 6.0 & 6.0 & -0.14 \\
06893590 & 178 & 5.8 & 5.8 & 0.03 \\
\hline
\end{tabular}

Table 5. HEC-RAS Model Validation for flood events of 27 April 2016 and 22 September 2017.

\begin{tabular}{ccccccccc}
\hline \multirow{2}{*}{ USGS Station } & \multicolumn{9}{c}{ Event $\mathbf{4 / 2 7 / 2 0 1 6}$} \\
\cline { 2 - 9 } & $\begin{array}{c}\text { Flow } \\
\left(\mathbf{m}^{\mathbf{3}} / \mathbf{s}\right)\end{array}$ & $\begin{array}{c}\text { Simulated } \\
\text { Stage } \\
(\mathbf{m})\end{array}$ & $\begin{array}{c}\text { Observed } \\
\text { Stage } \\
(\mathbf{m})\end{array}$ & $\begin{array}{c}\text { Difference } \\
(\mathbf{m})\end{array}$ & $\begin{array}{c}\text { Flow } \\
\left(\mathbf{m}^{\mathbf{3}} / \mathbf{s}\right)\end{array}$ & $\begin{array}{c}\text { Simulated } \\
\text { Stage } \\
(\mathbf{m})\end{array}$ & $\begin{array}{c}\text { Observed } \\
\text { Stage } \\
(\mathbf{m})\end{array}$ & $\begin{array}{c}\text { Difference } \\
(\mathbf{m})\end{array}$ \\
\hline 06893500 & 239 & 7.3 & 7.0 & -0.34 & 1203 & 15.4 & 14.1 & -1.31 \\
06893530 & 1171 & 16.1 & 14.9 & -1.19 & 237 & 6.6 & 7.2 & 0.59 \\
06893553 & 1162 & 13.8 & 14.4 & 0.63 & 236 & 6.5 & 7.1 \\
06893578 & 1154 & 12.6 & 10.7 & -1.88 & 235 & 6.5 & 6.3 & -0.61 \\
06893590 & 1138 & 11.2 & 9.5 & -1.63 & 233 & 6.3 & 5.5 \\
\hline
\end{tabular}

\subsection{Flood Inundation Mapping}

Accurate prediction of the flood inundation area for a given flood event is necessary for risk mitigation strategies. Over the last few decades, there have been vast improvements in flood inundation modeling [46]. While empirical methods are considered adequate for flood monitoring and post-disaster assessment, hydrodynamic models are critical to represent detailed flow dynamics to investigate impacts of management strategies such as dam break, flash floods, etc. Simplified conceptual models are usually adopted for probabilistic flood risk assessment on a large floodplain with well-defined channels. Different modeling approaches produce different predictions highlighting the uncertainty associated with the modeling practices, which is mainly generated by uncertainty in the design flow, terrain elevations, water surface elevations, and accuracy of the techniques used for mapping the inundation area [47].

In this study, the flood inundation area was developed using ArcGIS based on the HEC-RAS simulation of desired flood event. The pseudo-validation of the developed inundation map was conducted by comparing it with inundation maps already developed by the USGS which was available to view/download from the USGS Flood Inundation Mapper (https://wimcloud.usgs.gov/apps/FIM/ FloodInundationMapper.html). Figures 7 and 8 show the comparison between inundation maps created by HEC-RAS simulation (right figures) with the USGS inundation maps (left figures) at two separate locations. The comparison was done visually by comparing important features along the Blue River. The maps fairly show comparable zones of inundated area in both cases. It is important to note that the discharge data used by HEC-RAS in developing the inundation extent was based on the "simulated" discharge data from the hydrologic model, which may have contributed greatly to the disagreements between the two maps. Moreover, the comparison was against the another simulated map as explained in the disclaimer by the USGS (https://fim.wim.usgs.gov/fim/) which states that "the flood boundaries shown were estimated based on water stages (water-surface elevations) and streamflows at selected USGS streamgages. Water-surface elevations along the stream reaches were 
estimated by steady-state hydraulic modeling, assuming unobstructed flow, and using streamflows and hydrologic conditions anticipated at the USGS streamgage(s)".

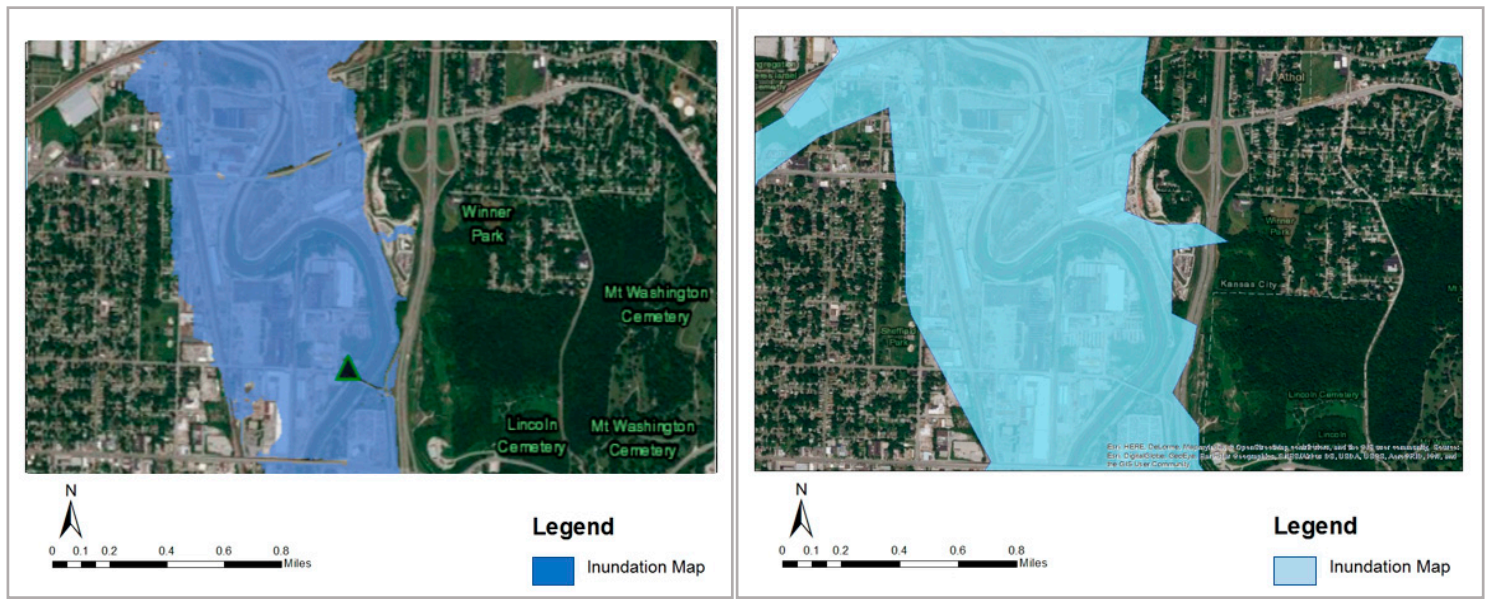

Figure 7. Comparison of the Inundation Map created by the HEC-RAS simulation (right-side) with the USGS (left-side) generated Inundation Map beside the Winner Park in Kansas City, MO.
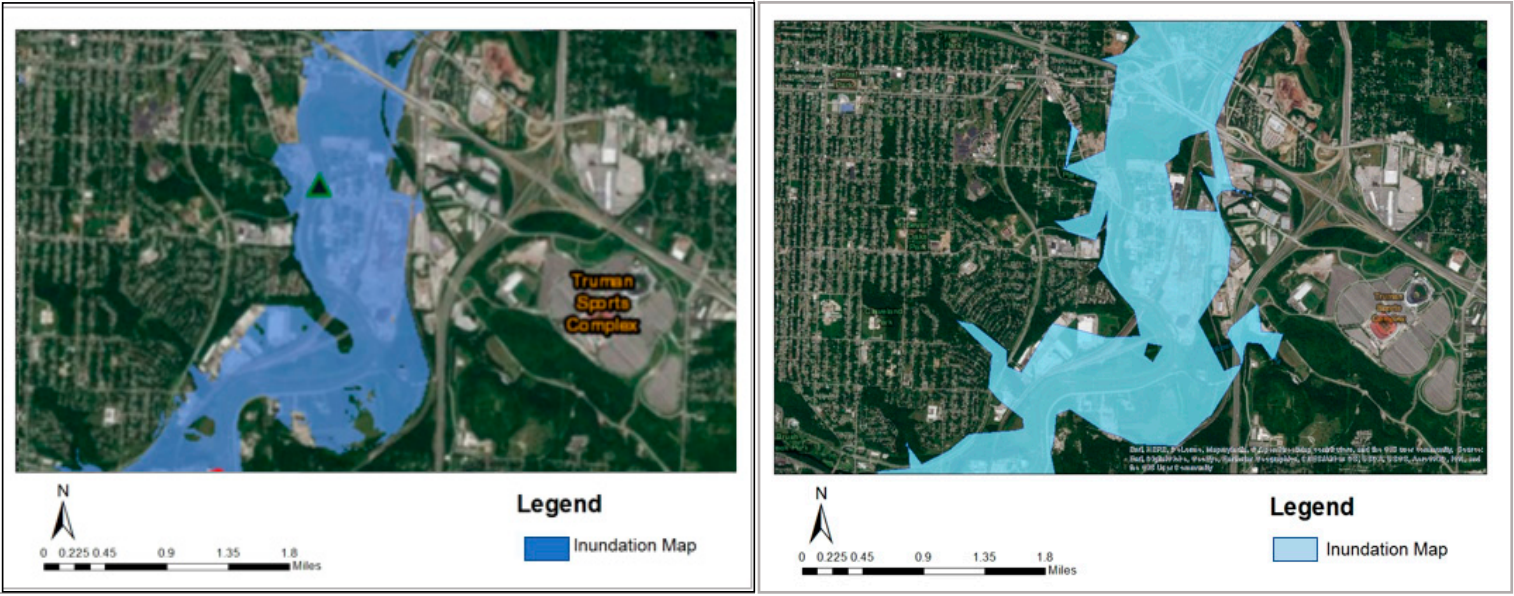

Figure 8. Comparison of the Inundation Map created by the HEC-RAS simulation (right-side) with the USGS (left-side) generated Inundation Map beside the Truman Sports Complex in Kansas City, MO.

\subsection{Vulnerability Assessment on Infrastructures}

Vulnerability assessment is an essential part of the flood management and preparedness process to reduce the impact. It requires an in-depth analysis of many factors including location of critical infrastructures such as hospitals, transportation routes and density of the population in order to increase the effectiveness of emergency plans. Indicators of flood hazard generally include the flood extent, water depth, flow velocity, duration, propagation of waterfront, and the rate at which the water rises [48]. These parameters are then linked with the economic damages and other vulnerability assessment. There are many studies linking inundation extent to determine economic losses or risks for planning purposes such as insurance, etc. [49]. The vulnerability criterion focused on human stability (not economic values) has also been analyzed using slipping, toppling, and drowning as indicators of human stability [50]. A flood modeling simulation in an urban area used inundation maps to analyze transport accessibility and human safety on pedestrians and drivers for its implications on emergency routes and service areas [51,52]. A comparative study of hydraulic models evaluated their capabilities for estimations of the vulnerability assessment to capture the uncertainties in the prediction [53]. 
In this study, we present the vulnerability assessment in terms of critical infrastructures being exposed to floodwaters by proximity to flood inundation extent over the study area. The analysis was based on flood event of May 2015. The infrastructures selected for vulnerability assessment purposes were local hospitals, transportation routes, airport facilities, and railroad networks. These infrastructures are very crucial for emergency responses such as for mitigation, preparedness, recovery, and response. For example, emergency response teams could use the inundation maps to optimize their routes to the flood affected locations, avoiding the inundated transportation routes. The inundation maps could also assist in the allocation of recovery resources from the high-risk zones following a flood event. Inundation maps could be created assuming a future storm event causing a flood, and therefore highly threatened flood zones could be alarmed ahead of time, thereby saving lives and resources.

\subsubsection{Impact of Inundation on Local Hospitals}

Hospitals are one of the major locations highly prioritized in the disaster mitigation process. Figure 9 depicts four hospitals that could be threatened due to similar flood situation like as May 2015. One of the four risked hospitals was identified to be almost under inundation and the rest could be impacted with an increase of a few units of water level caused by a more hazardous flood. The surrounding hospitals could be indirectly affected due to the closure of the nearby transportation routes. This vulnerability identification could help the management authorities warn the hospitals listed under the adverse impact, ahead of any upcoming hazards. The vulnerable hospitals showed in Figure 9 are listed in Table 6 with their distance from the inundation area. To understand the different levels of flood vulnerability, a ranking is given to the hospitals with respect to the distance of the hospitals from the flood extent at their respective locations.

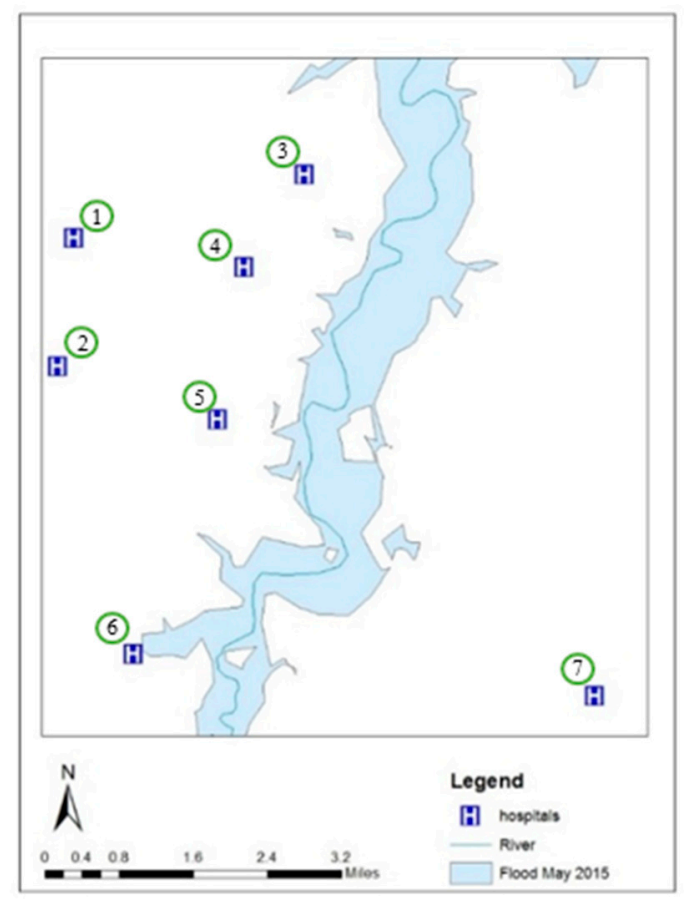

Figure 9. Location of hospitals in and around the inundated area due to Flood of May 2015. 
Table 6. List of hospitals vulnerable to the flood of May 2017 in Kansas City, Missouri.

\begin{tabular}{ccc}
\hline Hospital Location (Figure 10) and Names & Distance from Inundation Area (km) & Vulnerability Rank \\
\hline $\begin{array}{c}\text { 1H. Seton Center Safety Net Clinics } \\
\text { 2H. Samuel U. Rodgers South Therapeutic }\end{array}$ & 3.3 & 7 \\
Intervention Center-Substance Abuse & 2.9 & 5 \\
3H. Samuel U. Rodgers McCoy Elementary School & 0.8 & 3 \\
Dental Clinic & 1.0 & 4 \\
4H. Kansas City Free Health Clinic-Eastside & 0.7 & 2 \\
5H. Veterans Affairs Medical Center & 0.1 & 1 \\
6H. Swope Health Services-Central & 3.0 & 6 \\
7H. Two Rivers Psychiatric Hospital & & \\
\hline
\end{tabular}

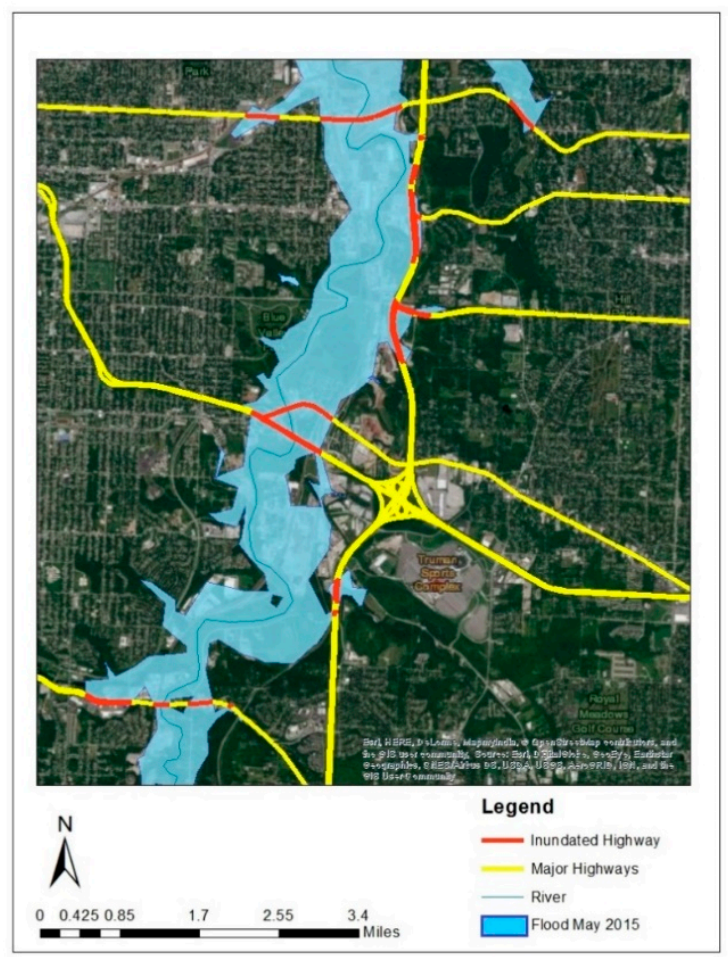

Figure 10. Location of major transportation routes under inundation due to the flood of May 2015.

\subsubsection{Impact of Inundation on Transportation Routes}

Intense precipitation is the foremost cause of weather-related disruption to the transportation sector [39]. It can cause severe damage to an area by obstructing the movement of people and goods, hampering social and economic functionality. The flooding on major transportation routes, like interstates and state highways, cut off the flooded zone's communication with the surrounding area which also delays the emergency management processes. Figure 10 shows the transportation routes that are directly affected due to the flooding scenario modeled for May 2015 flood. Parts of the interstate I70, Blue Parkway, Highway I435, Highway US 40, and Independence Avenue are found to be under the impact of inundation caused by the flood of May 2015 as simulated by HEC-RAS.

\subsubsection{Impact of Inundation on Airport}

Figure 11 shows the threatened location of Airports due to flood of May 2015. One of the airport facilities will be directly affected by the flood and the other one is very close by the inundated regions. A ranking is given to airports for flood vulnerability with respect to the distance of the facility from the inundation map at their respective locations (Table 7). 


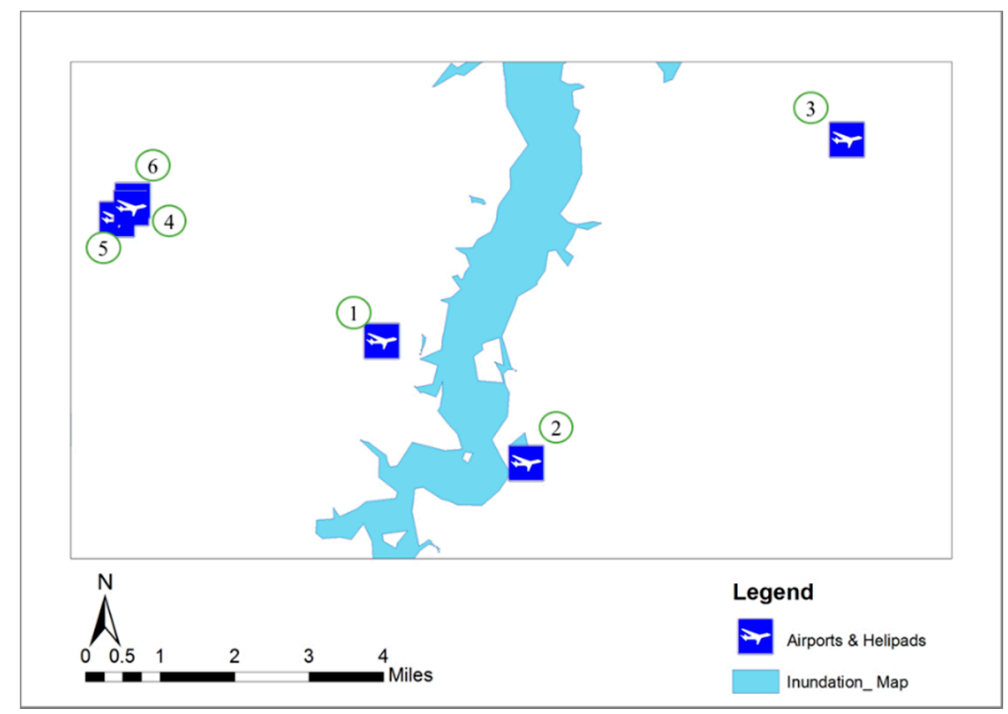

Figure 11. Location of airport under inundation due to the Flood of May 2015.

Table 7. List of airports vulnerable to the flood of May 2017 in Kansas City, Missouri.

\begin{tabular}{ccc}
\hline Airport Location (Figure 12) and Names & Distance from Inundation Map (m) & Vulnerability Rank \\
\hline 1. VA Medical Center Heliport & 670 & 2 \\
2. Police Department Helipad Main Facility & 126 & 1 \\
3. Independence RGNL Health Center Heliport & 3041 & 3 \\
4. Truman Medical Center West Heliport & 5316 & 4 \\
5. Children's Mercy Hospital Heliport & 5465 & 6 \\
6. Bert Walter Berkowitz Heliport & 5341 & 5 \\
\hline
\end{tabular}

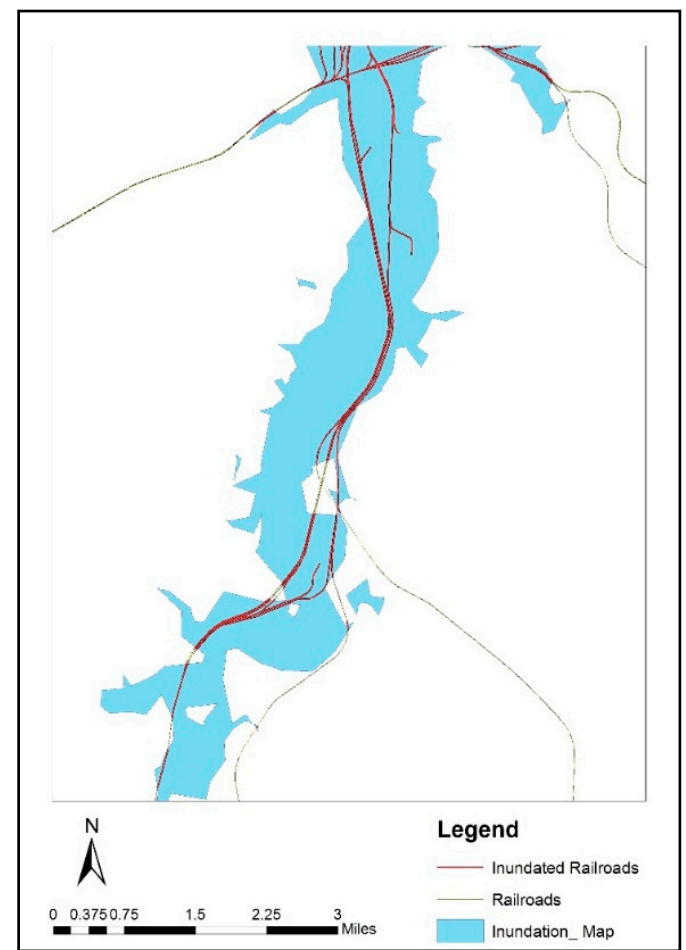

Figure 12. Location of railroad routes under inundation due to the Flood of May 2015.

\subsubsection{Impact of Inundation on Railroad Facilities}

The railroad is one of the most used routes in big cities and metropolitan areas. Inundated railroads could cause fatal accidents that would affect huge numbers of people travelling in the trains. Figure 12 
shows the location of railroad routes under inundation due to the flood of May 2015 as simulated by HEC-RAS. Railroads that are subjected to inundation will result in obstruction of the whole rail route within and surrounding the city. Table 8 provides the coverage of railroads under the flood.

Table 8. List of railroads vulnerable to the flood of May 2017 in Kansas City, Missouri.

\begin{tabular}{cc}
\hline Name of Railroad & Length Under Inundation (m) \\
\hline BNSF RR & 3014 \\
KCS RR & 3844 \\
KCT RR & 2390 \\
Missouri Central RR & 362 \\
Private RR & 333 \\
UP RR & 5750 \\
\hline
\end{tabular}

\section{Discussion and Conclusion}

This study presents a systematic approach of combining hydrodynamic model HEC-RAS with hydrologic model SWAT in delineating flood inundation zones and subsequently assessing the vulnerability of critical infrastructures in the Blue River Watershed in Kansas City, Missouri. Both models were independently calibrated and validated using various datasets and proven strategies. The HEC-RAS flood simulation model was found to be suitable in simulating flood events and spatially depicting the vulnerability of the region towards a hazard event in terms of inundation extent, whereas SWAT was proven to be a powerful tool in generating simulated flood hydrographs at desired locations. The models developed can be said to have generated reliable quantified output based on the statistical evaluation results. This study approach provides quantified information on the hydrologic modeling, hydrodynamic modeling, and flood prediction and analysis for flood management strategies.

The catastrophic possessions of flood disaster could be mitigated by integrating scientifically reliable information with the flood inundation map developed using this study approach. Vulnerability assessment approach used in this study for identifying and providing a vulnerability rank based on proximity to flood area is a simple yet powerful approach. It not only identified most to least vulnerable critical infrastructures, but also provided enough information for flood preparedness processes that could significantly reduce the impact. The approach could easily be extended for the vulnerability evaluation of other infrastructures in order to estimate economic losses, navigation route of people including high density area, and other region-specific important factors. Moreover, futuristic higher magnitude flood events can be simulated to assess magnified vulnerability and associated risks. Land use planning decisions could be made based on the flood inundation map which indicates the floodplains. Following such approaches will help save lives and resources at the same time, and provide a proven and more accurate way to contest the uncertainties of the natural events causing flood.

The flood modeling system presented in this study is an integrated system to stakeholders to investigate potential mitigation options and strategies in response to expected flooding scenarios. The use of hydrologic model in flood modeling proves very useful in studying alternative "what if" scenarios such as impacts of projected land use changes, climate variabilities, urban planning strategies and others. For all plausible scenarios, a well-calibrated hydrologic model of the region can easily simulate new conditions and yield changes in flow hydrographs at desired locations, which can then be translated into flood depths over the region using hydrodynamic models. A previous flood modeling attempt in Kansas River basin, close to the study watershed, used hydrologic model HEC-HMS (Hydrologic Modeling System) to generate estimates of peak flows for design storm for different land use scenarios [4]. The output was then used to execute the HEC-RAS model for estimates of water elevations and flood inundation extents for those design storms and land use scenarios. The results provided useful information, however the study was designed at a macro scale of change which does not necessarily reflect the flooding impacts at smaller scale. 
Added benefits of this combined modeling presented in this study system also includes the flexibility of hydrodynamic modeling for testing flood reduction or mitigation strategies through channel modifications and other best management practices within the floodplains areas. Such a modeling system also enables the assessment and determination of vulnerable areas that will not be able to receive effective adaptation solutions, which then calls for drastic measures to mitigate flood-prone impacts.

Such modeling application also comes with several limitations, including the availability, resolution, and accuracy of the data for the development, calibration, and validation of the models, the integration methods such as external coupling approach used in this study, flexibility provided by the statistical performance measures for the approval of a robust model, and ability to replicate/simulate best management practices with a degree of accuracy to support flood mitigation and adaptation options. As such, in the application presented in this study, major limitations in using hydrologic model may include (a) limited accuracy in model calibration and validation: resolution of the input data and limited set of observation data, e.g., calibrating only for the monthly flow and only at the watershed outlet, and (b) simulated data to be exported as input to another model: calibrated models produced simulated hydrographs to be used as input boundary conditions in hydrodynamic modeling. Similarly, sources of uncertainties in using hydrodynamic modeling may include input data quality of topography and surface roughness characterization as it affect both flow area and velocity [54,55]. The role of topography on flood studies has been discussed in many past studies [56], but the role of surface roughness has received less attention. A recent study exhibits the sensitiveness of surface roughness and highlights the source of uncertainties in flood modeling studies [57]. Reducing the uncertainty in surface roughness will greatly enhance the calculation of flood extent on landscapes. It is also noteworthy to mention that, while surface roughness plays an important role in simulating accurate flow hydrodynamics in both the channel and floodplain, Manning's $\mathrm{n}$ is not viewed as important (less-sensitive parameter) in simplified hydrological modeling.

Moreover, the errors in the simulation results from the combined modeling system of flood analysis arise from various sources of uncertainties, as discussed above, which probably propagates in an unknown and non-linear fashion. The next level of analysis should shed light on the assessment and quantification of these errors and how these propagate through the modeling system.

Author Contributions: Conceptualization, M.K.J.; methodology, M.K.J. and S.A.; software, M.K.J.; validation, M.K.J. and S.A.; formal analysis, S.A.; investigation, S.A. and M.K.J.; resources, S.A.; data curation, S.A.; writing-original draft preparation, S.A. and M.K.J.; writing—review and editing, M.K.J. All authors have read and agreed to the published version of the manuscript.

Funding: This research received no external funding.

Conflicts of Interest: The authors declare no conflict of interest.

\section{References}

1. Bronstert, A. Floods and climate change: Interactions and impacts. Risk Anal. 2003, 23, 545-557. [CrossRef]

2. Dang, N.M.; Babel, M.S.; Luong, H.T. Evaluation of food risk parameters in the Day River Flood Diversion Area, Red River Delta, Vietnam. Nat. Hazards 2011, 56, 169-194. [CrossRef]

3. Khan, S.I.; Hong, Y.; Gourley, J.J.; Khattak, M.U.; De Groeve, T. Multi-Sensor Imaging and Space-Ground Cross-Validation for 2010 Flood along Indus River, Pakistan. Remote Sens. 2014, 6, 2393-2407. [CrossRef]

4. Yuan, Y.; Qaiser, K. Floodplain Modeling in the Kansas River Basin Using Hydrologic Engineering Center (HEC) Models: Impacts of Urbanization and Wetlands for Mitigation; US Environmental Protection Agency: Washington, DC, USA, 2011; pp. 1-32.

5. Ramírez, J.A. Prediction and modeling of flood hydrology and hydraulics. In Inland Flood Hazards: Human, Riparian and Aquatic Communities; Ellen, W., Ed.; Cambridge University Press: London, UK, 2010; Chapter 11.

6. Arnold, J.G.; Moriasi, D.N.; Gassman, P.W.; Abbaspour, K.C.; White, M.J.; Srinivasan, R.; Santhi, C.; Harmel, R.D.; Van Griensven, A.; Van Liew, M.W.; et al. SWAT: Model Use, Calibration, and Validation. Trans. ASABE 2012, 55, 1491-1508. [CrossRef] 
7. Jha, M.K. Evaluating Hydrologic Response of an Agricultural Watershed for Watershed Analysis. Water 2011, 3, 604-617. [CrossRef]

8. Panagopoulos, Y.; Gassman, P.W.; Jha, M.K.; Kling, C.L.; Campbell, T.; Srinivasan, R.; White, M.; Arnold, J.G. A refined regional modeling approach for the Corn Belt-Experiences and recommendations for large-scale integrated modeling. J. Hydrol. 2015, 524, 348-366. [CrossRef]

9. Baffaut, C.; Dabney, S.M.; Smolen, M.D.; Youssef, M.A.; Bonta, J.V.; Chu, M.L.; Guzman, J.A.; Shedekar, V.S.; Jha, M.K.; Arnold, J.G. Hydrologic and Water Quality Modeling: Spatial and Temporal Considerations. Trans. ASABE 2015, 58, 1661-1680.

10. Guzman, J.A.; Shirmohammadi, A.; Sadeghi, A.M.; Wang, X.; Chu, M.L.; Jha, M.K.; Parajuli, P.B.; Harmel, R.D.; Khare, Y.P.; Hernandez, J.E. Uncertainty Considerations in Calibration and Validation of Hydrologic and Water Quality Models. Trans. ASABE 2015, 58, 1745-1762.

11. Shustikova, I.; Domeneghetti, A.; Neal, J.C.; Bates, P.; Castellarin, A. Comparing 2D capabilities of HEC-RAS and LISFLOOD-FP on complex topography. Hydrol. Sci. J. 2019, 64, 1769-1782. [CrossRef]

12. Patel, D.; Ramirez, J.A.; Srivastava, P.K.; Bray, M.; Han, D. Assessment of flood inundation mapping of Surat city by coupled 1D/2D hydrodynamic modeling: A case application of the new HEC-RAS 5. Nat. Hazards 2017, 89, 93-130. [CrossRef]

13. Pinos, J.; Timbe, L. Performance assessment of two-dimensional hydraulic models for generation of flood inundation maps in mountain river basins. Water Sci. Eng. 2019, 12, 11-18. [CrossRef]

14. Liu, Z.; Zhang, H.; Liang, Q. A coupled hydrological and hydrodynamic model for flood simulation. Hydrol. Res. 2019, 50, 589-606. [CrossRef]

15. Hunter, N.M.; Bates, P.D.; Horritt, M.S.; Wilson, M. Simple spatially-distributed models for predicting flood inundation: A review. Geomorphology 2007, 90, 208-225. [CrossRef]

16. De Paiva, R.C.; Collischonn, W.; Tucci, C.E. Large scale hydrologic and hydrodynamic modeling using limited data and a GIS based approach. J. Hydrol. 2011, 406, 170-181. [CrossRef]

17. Kim, J.; Warnock, A.; Ivanov, V.Y.; Katopodes, N.D. Coupled modeling of hydrologic and hydrodynamic processes including overland and channel flow. Adv. Water Resour. 2012, 37, 104-126. [CrossRef]

18. Lerat, J.; Perrin, C.; Andréassian, V.; Loumagne, C.; Ribstein, P. Towards robust methods to couple lumped rainfall-Runoff models and hydraulic models: A sensitivity analysis on the Illinois River. J. Hydrol. 2012, 418, 123-135. [CrossRef]

19. Thompson, J.R. Simulation of Wetland Water-Level Manipulation Using Coupled Hydrological/Hydraulic Modeling. Phys. Geogr. 2004, 25, 39-67. [CrossRef]

20. Bellos, V.; Tsakiris, G. A hybrid method for flood simulation in small catchments combining hydrodynamic and hydrological techniques. J. Hydrol. 2016, 540, 331-339. [CrossRef]

21. Bout, B.; Jetten, V. The validity of flow approximations when simulating catchment-integrated flash floods. J. Hydrol. 2018, 556, 674-688. [CrossRef]

22. Costabile, P.; Costanzo, C.; De Bartolo, S.; Gangi, F.; Macchione, F.; Tomasicchio, G.R. Hydraulic Characterization of River Networks Based on Flow Patterns Simulated by 2-D Shallow Water Modeling: Scaling Properties, Multifractal Interpretation, and Perspectives for Channel Heads Detection. Water Resour. Res. 2019, 55, 7717-7752. [CrossRef]

23. Pato, J.F.; Caviedes-Voullième, D.; García-Navarro, P. Rainfall/runoff simulation with 2D full shallow water equations: Sensitivity analysis and calibration of infiltration parameters. J. Hydrol. 2016, 536, 496-513. [CrossRef]

24. Caviedes-Voullième, D.; García-Navarro, P.; Murillo, J. Influence of mesh structure on 2D full shallow water equations and SCS Curve Number simulation of rainfall/runoff events. J. Hydrol. 2012, 448, 39-59. [CrossRef]

25. Cea, L.; Bladé, E. A simple and efficient unstructured finite volume scheme for solving the shallow water equations in overland flow applications. Water Resour. Res. 2015, 51, 5464-5486. [CrossRef]

26. Arnold, J.G.; Srinivasan, R.; Muttiah, R.S.; Williams, J.R. Large area hydrologic modeling and assessment part I: Model development. JAWRA J. Am. Water Resour. Assoc. 1998, 34, 73-89. [CrossRef]

27. HEC. HEC-RAS River Analysis System User's Manual Version 5.0; Hydrologic Engineering Center: Davis, CA, USA, 2016.

28. Wilkison, D.H.; Armstrong, D.J.; Norman, R.D.; Poulton, B.C.; Furlong, E.T.; Zaugg, S.D. Water Quality in the Blue River Basin, Kansas City Metropolitan Area, Missouri and Kansas, July 1998 to October 2004; Scientific Investigations Report; US Geological Survey: Reston, VA, USA, 2006; Volume 5147, 170p. 
29. Heimann, D.C.; Kelly, B.P.; Studley, S.E. Flood-Inundation Maps and Wetland Restoration Suitability Index for the Blue River and Selected Tributaries, Kansas City, Missouri, and Vicinity, 2012; Scientific Investigations Report; US Geological Survey: Reston, VA, USA, 2015; Volume 5180, 23p.

30. Missouri Department of Natural Resources. Water Protection Program: Total Maximum Daily Loads (TMDLs) for Blue River Jackson County, Missouri. Available online: https://dnr.mo.gov/env/wpp/tmdl/docs/ 0417-0418-0419-0421-blue-river-tmdl.pdf (accessed on 15 May 2020).

31. Amatya, D.M.; Jha, M.K.; Edwards, A.E.; Williams, T.M.; Hitchcock, D.R. SWAT-based phosphorus modeling of a karst watershed with an embayment, South Carolina. J. Environ. Prot. 2012, 4, 75-90. [CrossRef]

32. Schilling, K.E.; Gassman, P.W.; Kling, C.L.; Campbell, T.; Jha, M.K.; Wolter, C.F.; Arnold, J.G. The potential for agricultural land use change to reduce flood risk in a large watershed. Hydrol. Process. 2013, 28, 3314-3325. [CrossRef]

33. Burkart, C.S.; Jha, M.K. Site-specific simulation of nutrient control policies: Integrating economic and water quality effects. J. Agric. Resour. Econ. 2012, 37, 20-23.

34. Feng, H.; Jha, M.; Gassman, P. The Allocation of Nutrient Load Reduction across a Watershed: Assessing Delivery Coefficients as an Implementation Tool. Rev. Agric. Econ. 2009, 31, 183-204. [CrossRef]

35. Jha, M.K.; Gassman, P.W.; Arnold, J.G. Water Quality Modeling for the Raccoon River Watershed Using SWAT. Trans. ASABE 2007, 50, 479-493. [CrossRef]

36. Kling, C.L.; Panagopoulos, Y.; Rabotyagov, S.S.; Valcu, A.M.; Gassman, P.W.; Campbell, T.; White, M.J.; Arnold, J.; Srinivasan, R.; Jha, M.K.; et al. LUMINATE: Linking agricultural land use, local water quality and Gulf of Mexico hypoxia. Eur. Rev. Agric. Econ. 2014, 41, 431-459. [CrossRef]

37. Jha, M.K.; Pan, Z.; Takle, E.S.; Gu, R. Impact of climate change on stream flow in the upper Mississippi River Basin: A regional climate model perspective. J. Geophys. Res. 2004, 109, 1-12. [CrossRef]

38. Jha, M.; Arnold, J.G.; Gassman, P.W.; Giorgi, F.; Gu, R.R. Climate chhange sensitivity assessment on upper mississippi river basin streamflows using swat. JAWRA J. Am. Water Resour. Assoc. 2006, 42, 997-1015. [CrossRef]

39. Jha, M.K.; Gassman, P.W.; Panagopoulos, Y. Regional changes in nitrate loadings in the Upper Mississippi River Basin under predicted mid-century climate. Reg. Environ. Chang. 2013, 15, 449-460. [CrossRef]

40. Takle, E.S.; Jha, M.; Lu, E.; Arritt, R.W.; Gutowski, W.J. Streamflow in the upper Mississippi river basin as simulated by SWAT driven by 20th Century contemporary results of global climate models and NARCCAP regional climate models. Meteorol. Z. 2010, 19, 341-346. [CrossRef]

41. Lu, E.; Takle, E.S.; Manoj, J. The Relationships between Climatic and Hydrological Changes in the Upper Mississippi River Basin: A SWAT and Multi-GCM Study. J. Hydrometeorol. 2010, 11, 437-451. [CrossRef]

42. Jha, M.K.; Gassman, P.W. Changes in hydrology and streamflow as predicted by a modelling experiment forced with climate models. Hydrol. Process. 2014, 28, 2772-2781. [CrossRef]

43. Chattopadhyay, S.; Jha, M.K. Hydrologic response due to projected climatic variability in Haw River Watershed, North Carolina, USA. Hydrol. Sci. J. 2016, 61, 495-506. [CrossRef]

44. Abbaspour, K.C.; Yang, J.; Maximov, I.; Siber, R.; Bogner, K.; Mieleitner, J.; Zobrist, J.; Srinivasan, R. Modelling hydrology and water quality in the pre-alpine/alpine Thur watershed using SWAT. J. Hydrol. 2007, 333, 413-430. [CrossRef]

45. Moriasi, D.N.; Arnold, J.G.; Van Liew, M.W.; Bingner, R.L.; Harmel, R.D.; Veith, T.L. Model Evaluation Guidelines for Systematic Quantification of Accuracy in Watershed Simulations. Trans. ASABE 2007, 50, 885-900. [CrossRef]

46. Teng, J.; Jakeman, A.; Vaze, J.; Croke, B.F.; Dutta, D.; Kim, S. Flood inundation modelling: A review of methods, recent advances and uncertainty analysis. Environ. Model. Softw. 2017, 90, 201-216. [CrossRef]

47. Merwade, V.; Olivera, F.; Arabi, M.; Edleman, S. Uncertainty in Flood Inundation Mapping: Current Issues and Future Directions. J. Hydrol. Eng. 2008, 13, 608-620. [CrossRef]

48. De Moel, H.; Van Alphen, J.; Aerts, J.C.J.H. Flood maps in Europe-Methods, availability and use. Nat. Hazards Earth Syst. Sci. 2009, 9, 289-301. [CrossRef]

49. Bermúdez, M.; Zischg, A.P. Sensitivity of flood loss estimates to building representation and flow depth attribution methods in micro-scale flood modelling. Nat. Hazards 2018, 92, 1633-1648. [CrossRef]

50. Milanesi, L.; Pilotti, M.; Ranzi, R. A conceptual model of people's vulnerability to floods. Water Resour. Res. 2015, 51, 182-197. [CrossRef]

51. Arrighi, C.; Pregnolato, M.; Dawson, R.; Castelli, F. Preparedness against mobility disruption by floods. Sci. Total. Environ. 2018, 654, 1010-1022. [CrossRef] 
52. Arrighi, C.; Oumeraci, H.; Castelli, F. Hydrodynamics of pedestrians' instability in floodwaters. Hydrol. Earth Syst. Sci. 2017, 21, 515-531. [CrossRef]

53. Costabile, P.; Costanzo, C.; De Lorenzo, G.; Macchione, F. Is local flood hazard assessment in urban areas significantly influenced by the physical complexity of the hydrodynamic inundation model? J. Hydrol. 2020, 580, 124231. [CrossRef]

54. Fu, J.-C.; Hsu, M.H.; Duann, Y. Development of roughness updating based on artificial neural network in a river hydraulic model for flash flood forecasting. J. Earth Syst. Sci. 2016, 125, 115-128. [CrossRef]

55. Pourali, S.H.; Arrowsmith, C.; Chrisman, N.; Matkan, A.A.; Mitchell, D. Topography Wetness Index Application in Flood-Risk-Based Land Use Planning. Appl. Spat. Anal. Policy 2014, 9, 39-54. [CrossRef]

56. Saksena, S.; Merwade, V. Incorporating the effect of DEM resolution and accuracy for improved flood inundation mapping. J. Hydrol. 2015, 530, 180-194. [CrossRef]

57. Liu, Z.; Merwade, V.; Jafarzadegan, K. Investigating the role of model structure and surface roughness in generating flood inundation extents using one- and two-dimensional hydraulic models. J. Flood Risk Manag. 2019, 12, e12347. [CrossRef]

(C) 2020 by the authors. Licensee MDPI, Basel, Switzerland. This article is an open access article distributed under the terms and conditions of the Creative Commons Attribution (CC BY) license (http://creativecommons.org/licenses/by/4.0/). 